\title{
Influence of Polyacrylamide on Corrosion Resistance of Mild Steel Simulated Concrete Pore Solution Prepared In Well Water
}

\author{
T. shanthi ${ }^{a^{*}}$, and S. Rajendran ${ }^{\mathrm{b}}$, \\ ${ }^{a}$ PG Department of Chemistry, Srinivasan College of Arts and Science ,Perambalur -621212,India. \\ ${ }^{b}$ Department of Chemistry, RVS School of Engineering and Technology, Dindigul,India.
}

Abstract: Corrosion resistance of mild steel in simulated concrete pore solution (SCPS) Prepared in well water in the absence and presence of polacrylamide (PAA) and $\mathrm{Zn}^{2+}$ has been evaluated by weight loss method. It is observed that when PAA is added the corrosion inhibition efficiency (IE) increases. As the concentration of PAA increases, inhibition efficiency also increases. Addition of $\mathrm{Zn}^{2+}$ improves of IE further. $50 \mathrm{ppm}$ of PAA has $60 \% \mathrm{IE} .100 \mathrm{ppm}$ of PAA shows $75 \%$ IE. When $50 \mathrm{ppm}$ of $\mathrm{Zn}^{2+}$ is added to the above system, both system shows $80 \%$ and $90 \%$ IE. The mechanistic aspects of corrosion inhibition have been investigated by polarization study and $A C$ impedance spectra. . Polaraization study suggests that the PAA-Zn ${ }^{2+}$ system functions as a mixed inhibitor system .AC impedance reveal the presence of a protective film on the metal surface.

Keywords: concrete corrosion, simulated concrete pore solution, mild steel, polyacrylamide.

\section{Introduction}

Corrosion is the destruction of metals and alloys by chemical and electro chemical reaction with its environment. It is a natural phenomenon which cannot be avoided but it can be controlled and prevented using appropriate techniques like metallic coating, anodic protection,cathodic protection and using inhibitors, etc. Inhibitors have very good role in the presence of corrosion inhibition. The organic inhibitors contain hetero atom like oxygen, nitrogen, sulphide and phosphorous. It shows better corrosion efficiency of the compounds containing hetero atom follows $\mathrm{O}<\mathrm{N}<\mathrm{S}<\mathrm{P}^{1-4}$ Application of polymers as corrosion inhibitors have been attracted several researchers. ${ }^{5-7}$ Corrosion inhibition by conducting polymer has been studied ${ }^{8}$. The studies on corrosion inhibition of polyacrylamide grafted with fenugreek mucilage and polyvinyl prolidone have been reported. ${ }^{10}$ A saturated solution of calcium hydroxide is used as simulated concrete pore solution. ${ }^{11-15}$ The aim of the present study is to investigate the corrosion resistance of mild steel in simulated concrete pore solution in presence of polyacrylamide and $\mathrm{Zn}^{2+}$ combination to mild steel in well water. The physico-chemical parameters of the well water taken in preset study are given (Table-1). The corrosion inhibition efficiency was collected using weight loss, polarization and AC impedance studies. The protective film formed on the metal surface .

Table 1. Parameters of well water.

\begin{tabular}{|c|c|}
\hline Parameter & Value \\
\hline $\mathrm{pH}$ & 8.38 \\
Conductivity & $31101 / \mathrm{cm} \Omega$ \\
TDS & $2013 \mathrm{ppm}$ \\
Chloride & $665 \mathrm{ppm}$ \\
Sulphate & $14 \mathrm{ppm}$ \\
Total hardness & $1100 \mathrm{ppm}$ \\
\hline
\end{tabular}

\section{Materials And Methods}

\section{Preparation of specimens}

Mild steel specimen was used in the present study.(Composition (wt\%):0.026 S, $0.06 \% \mathrm{P}, 0.4 \% \mathrm{Mn}, 0.1 \%$ $\mathrm{C}$ and balance iron ${ }^{16}$ ) of the dimensions $1.0 \times 4.0 \times 0.2 \mathrm{~cm}$ were polished to a mirror finish and decreased with trichloroethylene and used for the weight loss method. 


\section{Simulated concrete pore solution (SCPS)}

A saturated calcium hydroxide solution is used in the present study,as SCP solution. The electrodes made of mild steel wire were immersed in the SCP solution polarization study and AC impedance was carried out.

\section{Mass-loss method}

Mild steel specimens in triplicate were immersed in $100 \mathrm{~mL}$ of simulated concrete pore solution (SCPS) containing various concentrations of the inhibitor in the presence and absence of $\mathrm{Zn}^{2+}$ for one day. The weight of the specimens before and after immersion was determined using Shimadzu balance, model AY 210. The corrosion products were cleansed with Clarke's solution.$^{17}$ Then the inhibition efficiency (I.E.) was then calculated using the equation(1)

$$
I . E=100[1-(\mathrm{W} 2 / \mathrm{W} 1)] \%
$$

Where $\mathrm{W}_{1}$ and $\mathrm{W}_{2}$ are the corrosion rates in the absence and presence of the inhibitor respectively. The corrosion rate(CR) was calculated using the formula(2).

$C R=[$ (Weight loss in $\mathrm{mg}) /$ (Area of the specimens in $\mathrm{dm}^{2} \mathrm{x}$ immersion period in days) $\mathrm{mdd}$ $----(2)$

\section{Potentiodynamic Polarization}

Polarization stud was carried out in Electrochemical impedence Analyser model CHI 660 A using a three electrode cell assembly was used. The woring electrode was used as a rectangular specimen of mild steel with the one face of the electrode of constant $1 \mathrm{~cm}^{2}$ area exposed.A saturated calomel electrode(SCE) was the reference electrode and platinum was the counter electrode . From the polarization study, corrosion parameters such as corrosion potential $\left(\mathrm{E}_{\text {corr }}\right)$ correction current $\left(\mathrm{I}_{\text {corr }}\right)$ and tafel slopes (anodic= ba and cathodic=bc) were calculated.

\section{AC impedance spectra}

The instrument used for polarization study was used to record AC impedance spectra also.The cell setup was the same. The real part $\left(\mathrm{Z}^{1}\right)$ and imaginary part $\left(\mathrm{Z}^{11}\right)$ of the cell impedance were measured in ohms at various frequencies. The values of the charge transfer resistance $\left(R_{t}\right)$ and the double layer capacitance $\left(C_{d 1}\right)$ were calculated.

\section{Analysis of weight loss study}

\section{Results And Discussion}

The calculated inhibition efficiencies (IE) and corrosion rates (CR) PAA in controlling corrosion mild steel immersed in simulated concrete pore solution in the absence and presense of $\mathrm{Zn}^{2+}$ ion are given in Table 2. The calculated value indicates the ability of PAA to be a good corrosion inhibitor.PAA alone shows some IE. But the combination of PAA $100 \mathrm{ppm}$ and $\mathrm{Zn}^{2+} 50 \mathrm{ppm}$ shows $90 \%$ IE. This suggest a synergitic effect exists between PAA and $\mathrm{Zn}^{2+}$ ion. ${ }^{18}$

Table 2

Inhibition efficiencies (IE\%) and corrosion rates (CR) obtained from PAA- $\mathrm{Zn}^{2+}$ system, when mild steel immersed in simulated concrete pore solution prepared in well water

\begin{tabular}{|c|c|c|}
\hline System & $I E \%$ & $C R$ mdd \\
\hline $50 \mathrm{ppm}$ PAA & 60 & 15.6 \\
\hline $100 \mathrm{ppm}$ PAA & 75 & 9.75 \\
\hline $50 \mathrm{ppm}$ PAA $+\mathrm{Zn}^{2+} 50 \mathrm{ppm}$ & 80 & 7.8 \\
\hline $100 \mathrm{ppm}$ PAA $+\mathrm{Zn}^{2+} 50 \mathrm{ppm}$ & 90 & 3.9 \\
\hline
\end{tabular}

\section{Analysis of polarization curves}

The potentiodynamic polarization curves of mild steel immersed in simulated concrete pore solution prepared in well water in the absence and presence of inhibitor are shown in Figure -1. The corrosion parameters such potential $\left(\mathrm{E}_{\text {corr }}\right)$,Tafel slopes $\left(\mathrm{b}_{\mathrm{c}}=\right.$ cathodic $; \mathrm{b}_{\mathrm{a}}=$ anodic),Linear polarization resistance(LPR) and corrosion current $\left(\mathrm{I}_{\text {corr }}\right)$ are given in Table -3 . When mild steel is immersed in SCPS the corrosion potential is $-591 \mathrm{mV}$ vs 
SCE (Saturated calomel electrode ) When $100 \mathrm{ppm}$ of PAA and $50 \mathrm{ppm}$ of $\mathrm{Zn}{ }^{2+}$ are added to the above system the corrosion potential shifted to the cathodic site $-658 \mathrm{mV}$ vs SCE. This indicates that the PAA- $\mathrm{Zn}^{2+}$ system $^{2}$ control the cathodic reaction predominantly. Further, the LPR value increase from $7965 \mathrm{ohmcm}^{2}$ to $17235 \mathrm{ohmcm}^{2}$ ,the corrosion current decreases from $4.187 \times 10^{-6} \mathrm{~A} / \mathrm{cm}^{2}$ to $1.877 \times 10^{-6} \mathrm{~A} / \mathrm{cm}^{2}$. Thus polarization study confirms the formatiom of a protective film on the metal surface. The anodic reaction is controlled by the formation of $\mathrm{Fe}^{2+}$ - PAA confirms on the anodic sites. The cathodic reaction (generation of $\mathrm{OH}^{-}$) is controlled by the formation of $\mathrm{Zn}(\mathrm{OH})_{2}$ on the cathodic sites on the metal surface. Thus anodic reaction and cathodic reaction are controlled. This accounts for synergistic effect. ${ }^{19,20}$

Table 3

Corrosion parameters of mild steel immersed in SCPS prepared well water in the absence and presence of inhibitor system obtained from potentiodynamic polarization study

\begin{tabular}{|c|c|c|c|c|c|}
\hline System & $\begin{array}{c}\text { Ecorr } \\
\mathrm{mV} \text { vs. SCE }\end{array}$ & $\begin{array}{c}\mathrm{b}_{\mathrm{c}} \\
\mathrm{mV} / \text { decade }\end{array}$ & $\begin{array}{c}\mathrm{b}_{\mathrm{a}} \\
\mathrm{mV} / \mathrm{decade}\end{array}$ & LPR ohmcm & $\begin{array}{c}\text { Icorr } \\
\mathrm{Acm}^{-2}\end{array}$ \\
\hline SCPS (blank) & -591 & 107 & 269 & 7965 & $4.187 \times 10^{-6}$ \\
\hline $\begin{array}{c}\text { SCPS + 100 ppm } \\
\text { PAA + 50ppm } \\
\mathrm{Zn}^{2+}\end{array}$ & -658 & 97 & 319 & 17235 & $1.877 \times 10^{-6}$ \\
\hline
\end{tabular}

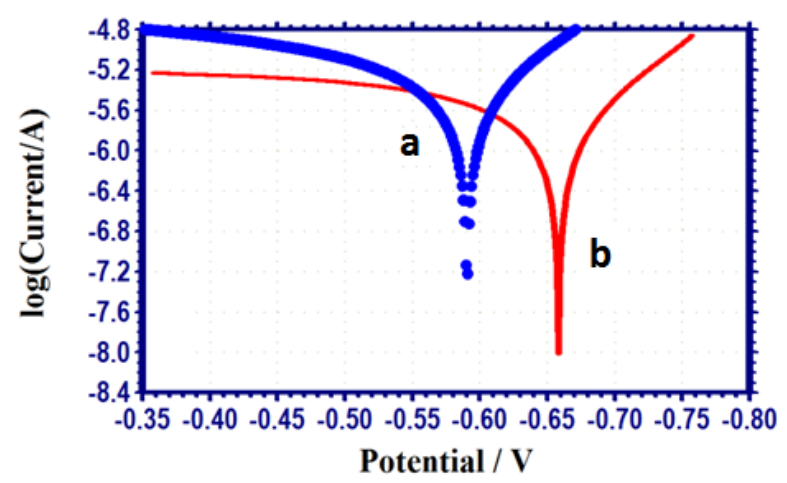

Figure 1. Polaraization curves of mild steel immersed in various test solution (a) SCPS (blank) (b) SCPS + PAA $100 \mathrm{ppm}+\mathrm{Zn}^{2+} 50 \mathrm{ppm}$

\section{Analysis of AC impedance spectra}

AC impedance spectra of mild steel immersed in simulated concrete pore solution prepared in well water in the absence and presence of inhibitor and $\mathrm{Zn}^{2+}$ are shown in the figs 2 to 4 . The nquist plots are shown in Fig 2 . The Bode plots are shown in Fig 3 and 4 . The charge transfer resistance $\left(R_{t}\right)$ and double layer capacitance $\left(C_{d 1}\right)$ values are derived from Nquist plots . Impadance values, $\log (\mathrm{z} / \mathrm{ohm})$ are derived from bode plots . The results are summarized in Table 4 .

Table 4

Impadance parameters of metals immersed in simulated concrete pore solution prepared in well water, obtained by AC impedance spectra

\begin{tabular}{|c|c|c|c|}
\hline \multirow{2}{*}{ System } & \multicolumn{2}{|c|}{ Nquist plot } & $\begin{array}{c}\text { Bode plot } \\
\log (\mathrm{z} / \mathrm{ohm})\end{array}$ \\
\cline { 2 - 4 } & $R_{\mathrm{t}} \mathrm{ohm} . \mathrm{cm}^{2}$ & $C_{\mathrm{dl}} \mathrm{Fcm}^{-2}$ & 3.4 \\
\hline $\begin{array}{c}\text { SCPS (blank) } \\
+50 \mathrm{ppm} \mathrm{Zn} \mathrm{Zn}^{2+}\end{array}$ & 3045 & $6.305 \times 10^{-9}$ & 3.9 \\
\hline
\end{tabular}

When corrosion rate decreases .due to formation of protective film, the charge transfer resistance value increases and double layer capacitance value decreases, the impedance value $\log (\mathrm{z} / \mathrm{ohm})$ increases. ${ }^{21-25}$. It is observed from Table 4, the $\mathrm{R}_{\mathrm{t}}$ value $3045 \mathrm{ohm} . \mathrm{cm}^{2}$, the $\mathrm{C}_{\mathrm{dl}}$ Value is $6.305 \times 10^{-9} \mathrm{Fcm}^{-2}$ and the impedance value is $3.4 \log$ 
(z/ ohm ). When $100 \mathrm{ppm}$ PAA and 50ppm $\mathrm{Zn}^{2+}$ are added to simulated concrete pore solution. The $\mathrm{R}_{\mathrm{t}}$ value 7315 ohm. $\mathrm{cm}^{2}$ increases, the $C_{\mathrm{dl}}$ Value is $2.624 \times 10^{-9} \mathrm{Fcm}^{-2}$ decreases and the impedance value is $3.9 \log (\mathrm{z} / \mathrm{ohm})$ increases. The increases charge transfer resistance $\left(\mathrm{R}_{\mathrm{t}}\right)$ value, tha double layer capacitance $\left(C_{\mathrm{dl}}\right)$ value decreases and the impedance value $(\mathrm{z})$ increases. This confirms the formation of protective film formed on the metal surface . This accounts for the better inhibition efficiency of the PAA $-\mathrm{Zn}^{2+}$

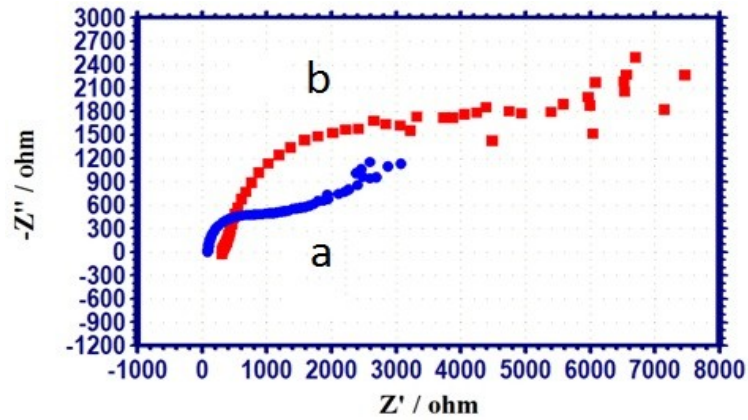

Figure 2. AC impedance spectrum of mild steel immersed in various test solution (a) SCPS(blank) (b) SCPS + PAA $100 \mathrm{ppm}+\mathrm{Zn}^{2+} 50 \mathrm{ppm}$ ( Nquist plot)
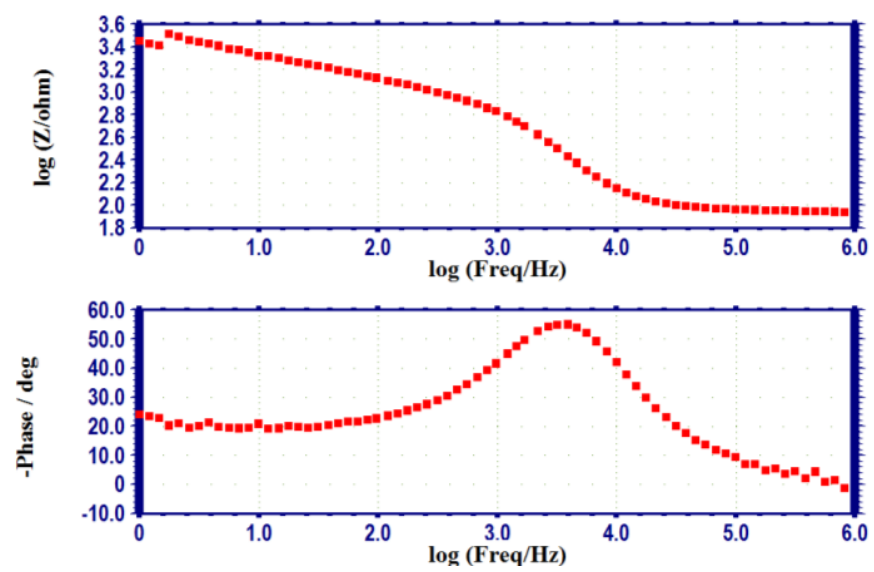

Figure 3. AC impedance spectrum of mild steel immersed in SCPS (Bode plot)
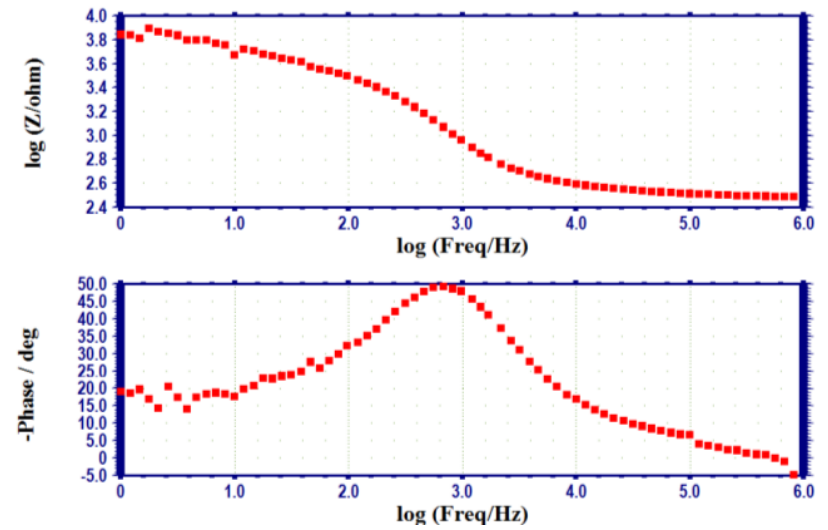

Figure 4. AC impedance spectrum of mild steel immersed in SCPS + PAA $100 \mathrm{ppm} \mathrm{Zn}^{2+} 50 \mathrm{ppm}$ (Bode plot ) 


\section{Conclusion}

The inhibition efficiency ( IE) of polyacrylamide (PAA) in controlling corrosion of mild steel immersed in simulated concrete pore solution prepared in well water in the absence of $\mathrm{Zn}^{2+}$ has been evaluated by weight loss method. The formulation consisting of $100 \mathrm{ppm}$ PAA and $50 \mathrm{ppm} \mathrm{Zn}^{2+}$ has $90 \%$ corrosion inhibition efficiency. Polarization study reveals that PAA $-\mathrm{Zn}^{2+}$ system controls the cathodic reaction predominantly. AC impedance spectra reveal that the formation of protective film on the metal surface.

\section{Acknowledgement}

The authors are thankful to their management and university grants commission, india, for the help and encouragement .

\section{References}

[1]. Thomas, G . N., Some New Fundamentals Aspects in Corrosion inhibition , 5th Euro.symp.corr. Inhibitors, Ferrara,Italy, 1981 ,453.

[2]. Doneelly ,B.D., Downie T.C.,Grzeskowaik R., Hamburg, H.R., and Short ,D., Corros. Sci., 1997,38,109

[3]. Tadros, A. B., and Abdel-Nab, Y.J., Electronal.Chem., 1998, $224,433$.

[4]. Subramaniam, N. C., Shesadri, B. S., and Mayanna, S. M., Corros .Sci., 1993, $34,563$.

[5]. Umoren, S.A., Ogbobe, O., Igwe I .O., and Ebenso, E .E., Corros. Sci., 2008, 50(7), 1998-2006

[6]. Srimathi, M., Rajalashmi, R., and Subhashini, R., Arab. J. Chem., 2010.

[7]. Umoren ,S. A., Solomon, M. M., Udosoro, I. I . and Udoh, A . P., Corros. Sci., 2010,17 (3),635-648.

[8]. Gelling, V. J., Wiest, M. M., Dennis, E. Tallman, Bierwagen G.P. and Wallace, G.G., Pro. Org .Coatings , 200143 (1-3), $149-157$.

[9]. Srivastava, V., Banerjee, S., Singh, M .M., J. Appl . poly. Sci., 2010,116 (2) ,810-816.

[10]. Umoren, S. A., Sur. Rev . Lett., 2009,16 (6) , 831-844.

[11]. Allaharam, S, R., Khodayari, M., Anti-Corros . Methods Mater, 2008, $55,250$.

[12]. Mennucci , M , M., Banczek , E. P., Rodrigues , P. R. P., Coasta, I., Cement Concrete Compos , 2009 , $418(28), 31$.

[13]. Kitowsi, C. J., Wheat, H. G., Corros ,1997, $53,216$.

[14]. Huriey, M. F., Scully, J. R., Corros , 2006, 62, 892.

[15]. Li , L., Sagues, A . A., Corros, $2004,60,195$.

[16]. Arocia Selvi, J., Rajendran, S., Garga Sri, V., John Amalraj, A., and Narayanaswamy, B., Port. Electrocheim. Acta, 2009, 27, 1.

[17]. Wranglen, G., Introduction to corrosion and protection of metals ( Chapman and Hall ,London), 1985,236.

[18]. Umoren, S. A., Li, Y., Wang, F. H., Corros , Sci ., 2010, 52 (5) , 1777-1786.

[19]. Agnesia Kanimozhi, S., and Rajendran, S., Int . J Electrochem. Sci., 2009, 4, 353-368.

[20]. Umoren, S. A., Ebenso, E. E., Matt. Chem. Phys., 2007, 106 (2-3),387-393

[21]. Leema Rose, A., Noreen Antony, Felicia RajarnmalSelva Rani, A., Peter pascal Regis and Rajendran, S., Zastit. Mater, 2009, 50 , 167.

[22]. Rajendran, S ., Kanagamani ,M., Sivakalaivani, M., Jeyasundari, J., Narayanasamy, B., and Rajam , K ., Zastita Marter , 2008 ,49, 19.

[23]. Sathiyabama, J., Rajendran, S., Arocia Selvi, J., Jeyasundari, J., The Open Corros . J, 2009, 2, 76.

[24]. Agnesia Kanimozhi, S., and Rajendran, S., Int. J. Electrochem. Sci, 2009, 4, 353.

[25]. Kalaivani, R., Narayanasamy, B., Selvi, J. A., Amalraj, A. J., Jeyasundari, J., and Rajendran, S., Port. Electrocheim . Acta, 2009, 27, 177. 